\title{
EVALUATION OF ANTIBACTERIAL POTENTIAL OF LEAF AND LEAF DERIVED CALLUS EXTRACTS OF ORTHOSIPHON ARISTATUS (BLUME) MIQ.
}

\author{
NISSAR AHMAD RESHI*, SUDARSHANA MYSORE SHANKARSINGH, GIRISH VASANAIKA HODIYALA
}

Department of Studies in Botany, University of Mysore, Mysuru, Karnataka, India. Email: nissarreshi@gmail.com

Received: 22 January 2016, Revised and Accepted: 20 February 2017

ABSTRACT

Objective: To evaluate the antibacterial efficacy of chloroform, petroleum ether, ethyl acetate, methanol, ethanol and aqueous extracts of leaf and leaf derived callus of Orthosiphon aristatus against Bacillus cereus, Bacillus subtiltis, Staphylococcus aureus, Streptococcus pyogenes, Enterobater aerogenes, Escherichia coli, Proteus mirabilis, and Klebsiella pneumoniae.

Materials and Methods: The leaf segments were cut into small pieces of size 1-2 sq cm and were cultured on Murashige and Skoog solid medium supplemented with different auxins alone and in combination. Antibacterial efficacy was performed by disc diffusion method followed by minimal inhibitory concentration (MIC) determination by two-fold serial dilution method. Leaf and leaf callus extracts were subjected to the qualitative phytochemical analysis.

Results: Maximum callus formation percentage was obtained from the leaf segments cultured on MS medium supplemented with 2, 4-D (2 mg/l). Ethanolic leaf extract showed maximum inhibition activity with $28 \mathrm{~mm}$ zone of inhibition against P. mirabilis with MIC value of $0.32 \mathrm{mg} / \mathrm{ml}$. Out of the callus extracts, ethanolic extract showed the maximum bio-efficacy against $S$. aureus with $26 \mathrm{~mm}$ zone of inhibition and MIC value of 0.64 mg/ml. Results revealed that both leaf and leaf derived callus extracts are effective against Gram-positive and Gram-negative test bacteria.

Conclusion: The bioefficacy study confirms the strong antibacterial potential of leaf and leaf derived callus extracts of 0 . aristatus.

Keywords: Leaf, Leaf callus, Antibacterial efficacy, Orthosiphon aristatus.

(C) 2017 The Authors. Published by Innovare Academic Sciences Pvt Ltd. This is an open access article under the CC BY license (http://creativecommons. org/licenses/by/4. 0/) DOI: http://dx.doi.org/10.22159/ajpcr.2017.v10i5.17231

\section{INTRODUCTION}

Plants as medicine have been used since ages and form the backbone of the primary health care system. It is necessary to establish a relation between traditional therapeutic value, biological activity, and chemical composition of medicinal plants. Popular observation and scientific validation of medicinal plants will significantly contribute to the development of natural and novel drug system. In India, medicinal plants constitute $50 \%$ of the higher flowering plant species [1]. Till date, approximately $20 \%$ of the medicinal plants have been subjected to the different biological assays [2]. Pharmaceutical industries invest considerable time and money in the development of the natural product-based drugs. Number of attempts has been made by far to develop an antibiotic of plant origin and still the efforts are on for this lead discovery. Although hundreds of medicinal plant species have been evaluated for their antibacterial properties, a vast majority has not been adequately evaluated [3].

Despite the advancement in science and technology infectious diseases claim millions of lives annually, especially in developing countries [4]. The treatment of infectious diseases faces a serious of issue of development of resistance by microbes against available antibiotics, which has necessitated a continuous search for the new antimicrobials of plant origin [5]. Today, multi-drug resistant bacteria such as methicillin resistant Staphylococcus aureus, vancomysin-resistant Enterococci Sp, Klebsiella pneumoniae, Escherichia coli, and Pseudomonas aeruginosa pose a serious threat to the human health. There is also an emergence of bacterial pathogens with intrinsic resistance to the available antibacterial agents, thus making them obsolete [6].

A proper approach needs to be adopted to counter this menace of antibiotic resistance. The search for new antimicrobials of plant origin could possibly counter the infectious disease threat and may lead to the discovery of natural and novel drug. Plants are rich source of antimicrobials and play an important role in the process of drug discovery and development [7]. In contrast to the synthetic antimicrobials, plant origin antibiotics are devoid of any ill effects and possess high therapeutic potential to counter infectious diseases. Screening of callus extracts for biological activities paves a way for the mass production of biologically viable secondary metabolites and thus provides an alternative to the in vivo plant material thereby minimizing any possible future threat to the natural habitat of medicinal plants.

Orthosiphon aristatus (Blume) Miq. also called as cat's whiskers, is an ethnomedicinal perennial herb and belongs to the family Lamiaceae, a native of Indonesia. It is $10-25 \mathrm{~cm}$ tall with quadrangular stem, leaves opposite, ovate to rhomboid with terminal inflorescence [8]. The plant is one of the most popular traditional folk medicines extensively used in Southeast Asia for the treatment of wide range of ailments. In Indonesia, leaves are used to treat rheumatism, diabetes mellitus, hypertension, tonsillitis, epilepsy, menstrual disorder, gonorrhoa, syphilis, renal calculi, gallstone, acute and chronic nephritis, gout arthritis, urinary tract, renal diseases, and fever [9-12]. It is also traditionally used to treat edema, eruptive fever, influenza, hepatitis, jaundice, and biliary lithiasis $[13,14]$. The medicinal property of the leaves of 0 . aristatus is attributed to the presence of bitter glycoside orthosiphon [15]. O. aristatus is patchily distributed and very rare in the field, hence, the conservation of this species is needed to ensure its sustainable utilization [16]. Bioefficacy potential of callus cultures sends a ray of hope for such highly medicinal plants, which if not protected may become extinct in near future.

In the present study, an attempt was made to screen the leaf and leaf callus extracts of $O$. aristatus for their antibacterial efficacy. 


\section{MATERIALS AND METHODS}

\section{Collection of plant material and callus induction}

O. aristatus plants were collected from the Nilgiri Hills, Western Ghats of Tamil Nadu (November 2012), and was authenticated by Dr. Md. Umer Sharief, Scientist C, at Botanical Survey of India, Yercaud-Salem, Tamil $\mathrm{Nadu}$, India, and are being maintained in the medicinal plant garden of Department of Studies in Botany, University of Mysore, Mysuru. Healthy leaf explants were collected from the mother plant and were washed under running tap water for 10 minutes to remove the soil and dust particles, followed by treatment with fungicide bavistin $(1 \% \mathrm{w} / \mathrm{v})$ for 5 minutes. Explants were then washed thrice with sterile double distilled water and were treated with mercuric chloride $(0.01 \% \mathrm{w} / \mathrm{v})$ for 5 minutes followed by washing thrice with sterile double distilled water. Inside laminar airflow, leaf explants were cut into small pieces (1 sq cm) and were inoculated onto the MS medium containing 3\% sucrose, $0.08 \%$ agar and fortified with different concentrations of auxins. Before autoclaving at $121^{\circ} \mathrm{C}$ for 15 minutes, $\mathrm{pH}$ of the medium was adjusted to 5.8 using $1 \mathrm{~N} \mathrm{NaOH}$ and $1 \mathrm{~N} \mathrm{HCl}$. The culture flasks were maintained in the incubation chamber under $16 \mathrm{hr}$ photo period at light intensity of $25 \mu \mathrm{mol} / \mathrm{s}^{2} / \mathrm{m}^{2}$ for 4 weeks. Each experiment was performed with five replicate and repeated thrice. The callus cultures were maintained for the period of 5 months and were periodically subcultured with 2-3 weeks of interval onto the fresh MS medium for callus proliferation. Subsequently, the callus was harvested at the transfer age of 3 weeks, kept in hot oven at $60^{\circ} \mathrm{C}$ for $24 \mathrm{hrs}$ till a constant dry weight was obtained, and the callus was then further exploited for extraction and antibacterial evaluation.

Dried leaves and the in vitro leaf derived callus were coarse powdered using electric homogenizer. Aqueous extraction was carried out by mixing leaf and leaf callus coarse powder separately with deionized water in the ratio of 1:5 $(\mathrm{w} / \mathrm{v})$ in conical flask and allowed to settle in an oven at $50^{\circ} \mathrm{C}$ for $72 \mathrm{hrs}$ with occasional shaking. After $72 \mathrm{hrs}$, the extracts were filtered using whatman filter paper [17]. The filtrate was lyophilized to dryness and stored in vials at $5^{\circ} \mathrm{C}$ for further use. Solvent extraction was carried out by taking $25 \mathrm{~g}$ of dry leaf and callus coarse powder and filled in a thimble separately and extracted sequentially with $200 \mathrm{ml}$ of petroleum ether, chloroform, ethyl acetate, ethanol, and methanol in soxhlet extractor for $48 \mathrm{hrs}$. The solvent extracts were concentrated under reduced pressure and were stored at $5^{\circ} \mathrm{C}$ in vials for further use.

The test bacteria; Gram-positive bacteria: Bacillus cereus (MTCC 430), Bacillus subtilis (MTCC 441), Staphylococcus aureus (MTCC 1144), Streptococcus pyogenes (MTCC 422). Gram-negative bacteria: Enterobacter aerogenes (MTCC 111), Escherichia coli (MTCC 1687), Proteus mirabilis (ATCC 7002), Klebsiella pneumoniae (MTCC 7407) were procured from MTCC Chandigarh, India. All the test bacteria were freshly subcultured once in a week during work on nutrient agar slants (Himedia) and were incubated at $37^{\circ} \mathrm{C}$ for $24 \mathrm{hrs}$. From $24 \mathrm{hr}$ old slant culture, a loop of inoculum was transferred to the $8 \mathrm{ml}$ nutrient broth (Himedia) and incubated for $24 \mathrm{hrs}$ at $37^{\circ} \mathrm{C}$ which was used as fresh suspension culture. The turbidity of bacterial suspension cultures was adjusted by adopting barium sulfate $\left(\mathrm{BaSO}_{4}\right)$ turbidity standard which is equivalent to $0.5 \mathrm{McF}$ arland standard [18], which gives $10^{6} \mathrm{CFU} / \mathrm{ml}$ bacteria $\left(1 \times 10^{6} \mathrm{cell} / \mathrm{ml}\right)$. Antibacterial activity of leaf and leaf callus extracts was screened by adopting disc diffusion assay $[19,20]$. Sterilized $20 \mathrm{ml}$ nutrient agar medium was transferred to the pre-autoclaved petriplates $(90 \mathrm{~mm})$ and allowed to solidify. $50 \mu \mathrm{l}$ of broth suspension bacterial culture (24 hr old) containing $10^{6} \mathrm{CFU} / \mathrm{ml}$ (0.5 McFarland standard) was put on to the solidified nutrient agar and was spread evenly using autoclaved glass spreader. Four impregnated discs $(6 \mathrm{~mm})$ were placed on inoculated nutrient agar in each petriplate, (i) leaf extract impregnated disc $(10 \mathrm{mg} / \mathrm{disc})$, (ii) leaf callus extract impregnated disc $(10 \mathrm{mg} / \mathrm{disc})$, (iii) standard streptomycin/gentamycin antibiotic disc $(10 \mathrm{mg} / \mathrm{disc})$ as reference drug, and (iv) solvent impregnated disc $(100 \mu \mathrm{l})$ as solvent negative control. The plates were kept in refrigerator at $5^{\circ} \mathrm{C}$ for 20 minutes to let extracts and controls diffuse into the agar. The plates were then incubated for $24 \mathrm{hrs}$ at $37^{\circ} \mathrm{C}$. Antibacterial activity was evaluated by measuring the diameter of zone of inhibition after $24 \mathrm{hrs}$ around each disc against the test bacteria. The experiment was repeated thrice, and statistical analysis was carried out using SPSS, DMRT with $\mathrm{p} \leq 0.5$.

The microplate (96 well) method was used to determine the minimal inhibitory concentration (MIC) of leaf and leaf callus extracts [21]. Initially, $100 \mu \mathrm{l}$ sterilized nutrient broth was put in each well of microplate. All the extracts (leaf and callus) were tested at $5 \mathrm{mg} / \mathrm{ml}$ and were serially diluted two-fold to $1 \mu \mathrm{g} / \mathrm{ml}$ after which $100 \mu \mathrm{l}$ of bacterial cultures $\left(10^{6} \mathrm{CFU} / \mathrm{ml}\right)$ were added to each well. The final volume in each well was $200 \mu \mathrm{l}$. In each assay, streptomycin was used as reference drug. Control wells were prepared with one containing culture medium only and the other with normal bacterial suspension culture. The contents of each well were mixed on a microplate shaker at $900 \mathrm{rpm}$ for 1 minute before incubation for $24 \mathrm{hrs}$ [22]. After $24 \mathrm{hr}, 20 \mu \mathrm{l}$ TTC solution (2,3,5-triphenyl tetrazolium chloride) prepared in deionized water $(20 \mathrm{mg} / \mathrm{ml})$ was added to each well and incubated for $1 \mathrm{hr}$ in dark [1,21]. The microbial growth in each well was determined by reading the respective absorbance at $600 \mathrm{~nm}$ using Universal Micro Plate Reader. The qualitative phytochemical analysis of leaf and leaf callus extracts was carried out by the method described by Zhang et al., (2016) [23].

\section{RESULTS}

Callus induction was observed along the cut edges of leaf segments after 2 weeks of inoculation on MS medium supplemented with auxins. Callus induction percentage varied with respect to the concentration of the growth regulator used and the age of the explant. Young explants cultured on MS medium augmented with 2,4-D (1 mg/l-3 mg/l) showed high percentage of callus induction and proliferation. IBA and NAA supplemented medium induced hard and compact callus with low percentage of proliferation (Table 1).

Antibacterial activity was carried out by disc diffusion assay, and the results revealed the antibacterial property of both in vivo leaf extracts and in vitro leaf callus extracts. Both leaf and leaf callus extracts inhibited the growth of test Gram-positive and Gram-negative bacteria. Out of the six leaf extracts (petroleum ether, chloroform, ethyl acetate,

Table 1: Influence of auxins on callus induction from the leaf segments of $O$. aristatus

\begin{tabular}{llll}
\hline $\begin{array}{l}\text { MS medium+plant } \\
\text { growth regulator } \\
\text { mg/l }\end{array}$ & $\begin{array}{l}\text { Mean } \\
\text { percentage } \\
\text { of callus } \\
\text { induction }\end{array}$ & $\begin{array}{l}\text { MS medium+plant } \\
\text { growth regulator } \\
\text { mg/l }\end{array}$ & $\begin{array}{l}\text { Mean } \\
\text { percentage } \\
\text { of callus } \\
\text { induction }\end{array}$ \\
\hline $2,4-\mathrm{D}$ & & IAA & \\
0.5 & 68 & 0.5 & 43 \\
1 & 86 & 1 & 47 \\
1.5 & 90 & 1.5 & 56 \\
2 & 90 & 2 & 62 \\
2.5 & 92 & 2.5 & 64 \\
3 & 98 & 3 & 70 \\
3.5 & 72 & 3.5 & 76 \\
4 & 70 & 4 & 79 \\
4.5 & 74 & 4.5 & 82 \\
5 & 68 & 5 & 78 \\
IBA & & NAA & \\
0.5 & 32 & 0.5 & 30 \\
1 & 42 & 1 & 36 \\
1.5 & 58 & 1.5 & 42 \\
2 & 58 & 2 & 46 \\
2.5 & 62 & 2.5 & 53 \\
3 & 68 & 3 & 68 \\
3.5 & 72 & 3.5 & 60 \\
4 & 65 & 4 & 68 \\
4.5 & 60 & 4.5 & \\
5 & 62 & 5 & \\
\hline 0.9 arstatus: & & & 68 \\
\hline
\end{tabular}

O. aristatus: Orthosiphon aristatus 
ethanol, methanol, and aqueous extracts), maximum growth inhibition was reported in ethanolic leaf extract against $P$. mirabilis with $28 \mathrm{~mm}$ zone of inhibition. Chloroform and petroleum ether extracts showed no or very less growth inhibition against test bacteria. Antibacterial activity and zone of inhibition of leaf extracts against test bacteria are given in Table 2.

Leaf callus extracts also showed promising growth inhibition against both Gram-positive and Gram-negative test bacteria. Nonpolar solvent callus extracts, i.e., chloroform and petroleum ether did not show any bacterial growth inhibition against any test bacteria. The maximum zone of inhibition was reported in ethanolic callus extract against $S$. aureus with $26 \mathrm{~mm}$ of inhibition zone. The zone of inhibition of different leaf callus extracts against different test bacteria is given in Table 3.

The extracts (both leaf and leaf callus) which inhibited the growth of test pathogens as revealed by disc diffusion method were subjected to MIC determination which provides quantitative data of minimum concentration of active extract which inhibits the bacterial growth. The MIC values of active leaf and leaf callus extracts were determined by two-fold serial dilution microplate method. The MIC values of leaf and leaf callus extracts are presented in Tables 4 and 5, respectively.

\section{DISCUSSION}

The study was aimed to evaluate the antibacterial property of leaf and leaf callus extracts of $O$. aristatus. Effect of auxins on callus induction has been reported earlier by many tissue culturists [24-26]. In the present study, 2,4-D supplemented MS medium was found to induce maximum callusing in leaf segments. Our results are in concurrence with the earlier findings carried out on Plumbago zeylanica [24] and Withania somnifera [27].

In the present study, leaf and leaf callus extracts of $O$. aristatus inhibited the growth of both Gram-negative and Gram-positive bacteria. Out of the extracts tested, non-polar solvent extracts (chloroform and petroleum ether) both from leaf and leaf callus showed little or no zone of inhibition against test bacteria. Moreno et al. (2006) [28] explained in their studies that less polar compounds diffuse slowly into the medium as they are hydrophobic in nature which prevents their uniform diffusion through agar medium. Out of all the extracts tested polar solvent (ethanol, methanol and aqueous) extracts of both leaf and leaf callus showed promising results.

Successful prediction of natural compounds from the plant or callus extract depends largely on the type of solvent used in the extraction

Table 2: Antibacterial activity (zone of inhibition in $\mathrm{mm}$ ) of leaf extracts of $O$. aristatus

\begin{tabular}{llllllll}
\hline Leaf extracts & \multicolumn{7}{c}{} \\
\hline Pathogen & Aqueous & Ethanol & Methanol & Ethyl acetate & Petroleum ether & Chloroform & Streptomycin \\
\hline B. cereus & $2 \pm 0.43$ & $3 \pm 0.65$ & $15 \pm 0.45$ & $4 \pm 0.65$ & $5 \pm 0.54$ & - & $40 \pm 0.55$ \\
B. subtilis & $4 \pm 0.32$ & $7 \pm 0.65$ & $9 \pm 0.34$ & $18 \pm 0.19$ & - & - & $35 \pm 0.65$ \\
S. pyogenes & - & $18 \pm 0.32$ & - & - & - & - & $38 \pm 0.43$ \\
S. aureus & $12 \pm 0.65$ & $14 \pm 0.78$ & $17 \pm 0.45$ & $10 \pm 0.65$ & $3 \pm 0.54$ & - & $35 \pm 0.23$ \\
E. coli & - & $12 \pm 0.67$ & $20 \pm 0.34$ & - & - & - & $40 \pm 0.53$ \\
P. mirabilis & - & $28 \pm 0.65$ & $15 \pm 0.36$ & - & - & - & $38 \pm 0.54$ \\
K. pneumoniae & - & $7 \pm 0.76$ & $26 \pm 0.56$ & - & - & - & $35 \pm 0.56$ \\
E. aerogenes & - & $13 \pm 0.54$ & - & - & - & $35 \pm 0.76$ \\
\hline
\end{tabular}

O. aristatus: Orthosiphon aristatus, B. cereus: Bacillus cereus, B. subtilis: Bacillus subtilis, S. pyogenes: Streptococcus pyogenes, S. aureus: Staphylococcus aureus,

E. coli: Escherichia coli, P. mirabilis: Proteus mirabilis, K. pneumonia: Klebsiella pneumonia, E. aerogenes: Enterobacter aerogenes

Table 3: Antibacterial activity (zone of inhibition in $\mathrm{mm}$ ) of leaf callus extracts of $O$. aristatus

\begin{tabular}{llllllll}
\hline \multicolumn{2}{l}{ Leaf callus extracts } \\
\hline Pathogen & Aqueous & Ethanol & Methanol & Ethyl acetate & Petroleum ether & Chloroform & Streptomycin \\
\hline B. cereus & - & $3 \pm 0.27$ & $10 \pm 0.45$ & - & - & - & $40 \pm 0.55$ \\
B. subtilis & - & $8 \pm 0.25$ & $2 \pm 0.54$ & & - & - & $35 \pm 0.65$ \\
S. pyogens & - & $10 \pm 0.15$ & - & - & - & - & $38 \pm 0.43$ \\
S. aureus & $3 \pm 0.42$ & $22 \pm 0.62$ & $3 \pm 0.45$ & $12 \pm 0.54$ & - & - & $35 \pm 0.23$ \\
E. coli & - & - & - & - & - & - & $40 \pm 0.53$ \\
P. mirabilis & - & $2 \pm 0.48$ & $14 \pm 0.67$ & - & - & - & $38 \pm 0.54$ \\
K. pneumonia & - & $20 \pm 0.41$ & $14 \pm 0.52$ & - & - & - & $35 \pm 0.56$ \\
E. aerogenes & - & - & - & - & - & $35 \pm 0.76$ \\
\hline
\end{tabular}

O. aristatus: Orthosiphon aristatus, B. cereus: Bacillus cereus, B. subtilis: Bacillus subtilis, S. pyogenes: Streptococcus pyogenes, S. aureus: Staphylococcus aureus,

E. coli: Escherichia coli, P. mirabilis: Proteus mirabilis, K. pneumonia: Klebsiella pneumonia, E. aerogenes: Enterobacter aerogenes

Table 4: Minimal inhibitory concentration $(\mathrm{mg} / \mathrm{ml})$ of leaf extracts of $O$. aristatus against test bacteria

\begin{tabular}{lllllllll}
\hline Test bacteria & \multicolumn{10}{c}{} \\
\hline Extracts & B. cereus & B. subtilis & S. pyogenes & S. aureus & E. coli & P. mirabilis & K. pneumoniae & E. aerogenes \\
\hline Aqueous & - & - & - & 2.50 & - & - & - & - \\
Ethanol & - & 2.50 & 1.25 & 2.50 & 1.25 & 0.32 & 2.50 & 1.25 \\
Methanol & 0.62 & 1.25 & - & 0.62 & 0.62 & 1.25 & 0.62 & - \\
Ethyl acetate & 2.50 & 1.25 & - & 1.25 & - & - & - & - \\
Petroleum ether & 5 & - & - & 2.50 & - & - & - & -2.50 \\
Chloroform & - & - & - & - & - & - & 0.50 & 0.25 \\
Streptomycin & 0.062 & 0.062 & 0.062 & 0.12 & 0.25 & 0.25 & 0 & \\
\hline
\end{tabular}

O. aristatus: Orthosiphon aristatus, B. cereus: Bacillus cereus, B. subtilis: Bacillus subtilis, S. pyogenes: Streptococcus pyogenes, S. aureus: Staphylococcus aureus,

E. coli: Escherichia coli, P. mirabilis: Proteus mirabilis, K. pneumonia: Klebsiella pneumonia, E. aerogenes: Enterobacter aerogenes 
Table 5: Minimal inhibitory concentration $(\mathrm{mg} / \mathrm{ml})$ of leaf callus extracts of $O$. aristatus against test bacteria

\begin{tabular}{|c|c|c|c|c|c|c|c|c|}
\hline \multicolumn{9}{|l|}{ Test bacteria } \\
\hline Extracts & B. cereus & B. subtilis & S. pyogenes & S. aureus & E. coli & P. mirabilis & K. pneumoniae & E. aerogenes \\
\hline Aqueous & - & - & - & 1.25 & - & - & - & - \\
\hline Ethanol & 5 & 2.50 & 1.25 & 0.64 & - & 2.50 & 1.25 & - \\
\hline Methanol & 2.5 & 1.25 & - & 5 & - & 0.62 & 0.62 & - \\
\hline Ethyl acetate & - & - & - & 1.25 & - & - & - & - \\
\hline Petroleum ether & - & - & - & - & - & - & - & - \\
\hline Chloroform & - & - & - & - & - & - & - & - \\
\hline Streptomycin & 0.062 & 0.062 & 0.062 & 0.12 & 0.25 & 0.25 & 0.50 & 0.25 \\
\hline
\end{tabular}

O. aristatus: Orthosiphon aristatus, B. cereus: Bacillus cereus, B. subtilis: Bacillus subtilis, S. pyogenes: Streptococcus pyogenes, S. aureus: Staphylococcus aureus,

E. coli: Escherichia coli, P. mirabilis: Proteus mirabilis, K. pneumonia: Klebsiella pneumonia, E. aerogenes: Enterobacter aerogenes

process. Traditional practioners widely use water as a solvent, but in our study, we found that organic solvents such as ethanol and methanol extracts exhibited more antibacterial activity against test bacteria than aqueous extract. Our studies are in concurrence with the earlier studies carried out by Martin, (1995) [29], Sanches et al., (2005) [30], Aboaba et al., (2006) [31], and Durmaz et al., (2006) [32], who reported that generally water extracts of plants do not have much activity against bacteria. Eloff, (1998) [21] reported in his study that ethanol and methanol extracts are most effective than water and other nonpolar solvent extracts, and the same is in concurrence with our study.

In the present study, leaf extracts were more effective against the Gram-negative bacteria which are more complex than Gram-positive ones; their cell walls are more complex and make them less susceptible to antibacterial agents [33,34]. According to Gupta and Saxena, (1984) [35] who reported that the judgment of strong antibacterial activity is based on MIC values between 0.05 and $0.50 \mathrm{mg} / \mathrm{ml}$, moderate activity on values between 0.6 and $1.50 \mathrm{mg} / \mathrm{ml}$, and week activity on values above $1.50 \mathrm{mg} / \mathrm{ml}$. In the present investigation, results revealed that the MIC values of the ethanolic leaf and leaf callus extract are $0.32 \mathrm{mg} / \mathrm{ml}$ and $0.64 \mathrm{mg} / \mathrm{ml}$, respectively, which demonstrates their strong antibacterial activity against $P$. mirabilis and $S$. aureus, respectively. Antibacterial activity of leaf callus extracts has been reported earlier in several medicinal plants earlier like Mentha arvensis [1] and Barleria lupulina [36]. Callus cultures are considered to be very useful in the production of antimicrobial principles and are considered a de novo production of the needed metabolites through cell culture [37,38]. Tejavathi and Rao, (1996) [39] reported in their study that callus and regenerated plants sometimes show enhancement of secondary metabolites when compared to in vivo plants. Hence, an attempt was made to carry out the antibacterial study of in vivo plant material and in vitro derived leaf callus of $O$. aristatus.

\section{CONCLUSION}

The study shows a strong correlation with the reported traditional medicinal use for the treatment of infectious diseases. Both leaf and leaf callus extracts exhibited antibacterial activity. The extracts were more effective against gram negative bacteria. Callus mediated cell lines can be explored for the mass production of viable antibacterial secondary metabolites. Further studies need to carry out to isolate and characterize the active principles from leaf and callus cultures.

\section{ACKNOWLEDGMENT}

Authors are grateful to the University of Mysore for providing all the necessary facilities to carry out this research.

\section{REFERENCES}

1. Johnson M, Wesely EG, Kavitha MS, Uma V. Antibacterial activity of leaves and inter-nodal callus extracts of Mentha arvensis L. Asian Pac J Trop Med 2011;4(3):196-200.

2. Suffredini JB, Sader HS, Goncalves AG, Reis AO, Gales AC, Varella $\mathrm{AD}$, et al. Screening of antimicrobial extracts from plants native to Brazilian amazon rainforest and Atlantic forest. Braz J Med Biol Res
2004;37:379-84.

3. Balandrin MJ, Klocke JA. Medicinal, Aromatic and Industrial Materials from Plants. Berlin: Bajaj Springer-Verlag; 1988. p. 1-36.

4. York $\mathrm{T}$, de Wet $\mathrm{H}$, van Vuuren SF. Plants used for treating respiratory infections in rural Maputaland, KwaZulu-Natal, South Africa. J Ethnopharmacol 2011;135(3):696-710.

5. Morens DM, Folkers GK, Fauci AS. The challenge of emerging and re-emerging infectious diseases. Nature 2004;430(6996):242-9.

6. Tenover FC. Mechanisms of antimicrobial resistance in bacteria. Am J Med 2006;119 6 Suppl 1:S3-10.

7. McGaw LJ, Lall N, Meyer JJ, Eloff JN. The potential of South African plants against Mycobacterium infections. J Ethnopharmacol 2008;119(3):482-500.

8. Keng H. Labiatae. Flora Malesiana 1978;(3):379-81.

9. Anonymous. Burmese Indigenous Medicinal Plants: Plants with Reputed Hypoglycemic Action. Yangon, Burma: Burma Medical Research Institute; 1967.

10. Anonymous. Medicinal Herb Index in Indonesia. Jakarta: Eisai Indonesia; 1995.

11. Kumpulan IH. Ramuan Obat Tradisioinal Indonesia. Sidoarjo: PJ Dayang Sumbi; 2005. p. 109-12.

12. Arisandi Y, Andriani Y. Khasiat Tanaman Obat. Jakarta: Penerbit Pustaka Buku Murah; 2006. p. 196-8.

13. Bwin DM, Gwan US. Ministry of health, health and myanmar traditional medicine. In: Burmese Indigenous Medicinal Plant: Plants with Reputed Hypoglycemic Action. Yangon, Burma: Burma Medical Research Institute; 1967. p. 126-8.

14. Awale S, Tezuka Y, Banskota AH, Kadota S. Siphonols A-E: Novel nitric oxide inhibitors from Orthosiphon stamineus of Indonesia. Bioorg Med Chem Lett 2003;13(1):31-5.

15. CSIR. Wealth of India: Raw Materials. New Delhi, India: Council of Scientific and Industrial Research; 1966. p. 168-70.

16. Rajendran SM, Chandrasekar K, Sundersan V. Ethanomedicinal lore of seithur hills-Southern Westen Ghats, Tamil Nadu. Ethnobotany 2001;13(3):101-9.

17. Harborne JB. Phytochemical Methods A Guide to Modern Techniques of Plant Analysis. London: Chapman and Hall; 1998. p. 182-90.

18. Doughari JH. Antimicrobial activity of Tamarindus indica Linn. Trop J Pharm Res 2007;5(2):597-603.

19. Anonymous. Pharmacopeia of India: The Indian Pharmacopeia. $3^{\text {rd }}$ ed. Government of India, New Delhi: Ministry of Family and Health Welfare; 1996

20. Hoffman BR, Delas AH, Blanco K, Wiederhold N, Lewis RE, Williams L. Screening of antibacterial and antifungal activities of ten medicinal plants from Ghana. Pharm Biol 2004;42(1):13-7.

21. Eloff JN. A sensitive and quick microplate method to determine the minimal inhibitory concentration of plant extracts for bacteria. Planta Med 1998;64(8):711-3.

22. Klancnik A, Piskernik S, Jersek B, Mozina SS. Evaluation of diffusion and dilution methods to determine the antibacterial activity of plant extracts. J Microbiol Methods 2010;81(2):121-6.

23. Zhang L, Zhang J, Qi B, Jiang G, Liu J, Zhang P, et al. The anti-tumor effect and bioactive phytochemicals of Hedyotis diffusa willd on ovarian cancer cells. J Ethnopharmacol 2016;192:132-9.

24. Rout GR, Saxena C, Samantaray S, Das P. Rapid plant regeneration from callus cultures of Plumbago zeylanica. Plant Cell Tissue Organ Cult 1999;56:47-51.

25. Jain SC, Jian R, Vlietinck JA. In vitro and in vivo antimicrobial efficacy of mimosa hamate. Indian J Biotechnol 2004;3:271-3.

26. Shariff N, Sudarshana MS, Umesha S, Hariprasad P. Antimicrobial 
activity of Rauvolfiate traphylla and Physalis minima leaf and leaf callus extracts. Afr J Biotechnol 2006;5:946-50.

27. Manickam VS, Elangomadhavan R, Antonisamy R. Regeneration of Indian ginseng plantlets from stem callus. Plant Cell Tissue Organ Cult 2000;14:55-8.

28. Moreno S, Scheyer T, Romano CS, Vojnov AA. Antioxidant and antimicrobial activities of rosemary extracts linked to their polyphenol composition. Free Radic Res 2006;40(2):223-31.

29. Martin GJ. Ethnobotany: A Methods Manual. Vol. 1. London: Chapman and Hall, Earthscan; 1995.

30. Sanches NR, Garcia Cortez DA, Schiavini MS, Nakamura CV, Dias-Filho BP. An evaluation of antibacterial activities of Psidium guajava (L.). Braz Arch Biol Technol 2005;48(3):429-36.

31. Aboaba OO, Smith SI, Olude FO. Antibacterial effect of edible plant extract on Escherichia coli 0157: H7. Pak J Nutr 2006;5(4):325-7.

32. Durmaz H, Sagun E, Tarakci Z, Ozgokce F. Antibacterial activities of Allium vineale, Chaerophyllum macropodum and Prangos ferulacea. Afr J Biotechnol 2006;5(19):1795-8.

33. Nostro A, Germanò MP, D'angelo V, Marino A, Cannatelli MA. Extraction methods and bioautography for evaluation of medicinal plant antimicrobial activity. Lett Appl Microbiol 2000;30(5):379-84

34. Tadeg H, Mohammed E, Asres K, Gebre-Mariam T. Antimicrobial activities of some selected traditional Ethiopian medicinal plants used in the treatment of skin disorders. J Ethnopharmacol 2005;100(1-2):168-75

35. Gupta HM, Saxena VK. A new acylated luteolin-7-0- $\beta$-D-glucoside from the roots of Barleria priontis (Lin). Natl Acad Sci Lett 1984;7(3):187-9

36. Moin S. Babu SS, Mahalakshmipriya A. In vitro callus production and antibacterial activity of Barleria lupulina. Asian Pac J Mol Biol Biotechnol 2012;20(2):59-64.

37. Sokmen A. Antiviral and cytotoxic activities of extracts from cell cultures and respective parts of some turkish medicinal plants. Turk $\mathbf{J}$ Biol 2001;12(5):343-50

38. Güllüce M, Sökmen M, Daferera D, Agar G, Ozkan H, Kartal N, et al. In vitro antibacterial, antifungal, and antioxidant activities of the essential oil and methanol extracts of herbal parts and callus cultures of Satureja hortensis L. J Agric Food Chem 2003;51:3958-65.

39. Tejavathi DH, Rao N. Comparative studies between normal and tissue culture plants of Bacopa monnieri. Role of Biotechnology in Medicinal and Aromatic Plants. Hyderabad: Ukkaz Publications; 1996. p. 239-49. 